\title{
NORTH EAST INDIA, DEPENDENCY SYNDROME AND ENERGY SECURITY: THE REALITY CHECK.
}

\author{
Dr. Aribam Devidas Sharma \\ Associate Professor, Department of Economics Manipur College, Imphal Manipur \\ DOI: 10.46609/IJSSER.2020.v05i06.010 URL: https://doi.org/10.46609/IJSSER.2020.v05i06.010
}

\begin{abstract}
The use of the term "Northeast" is itself problematic as the region represents a varied cultural mosaic and has never considered itself to be one compact unit. One has to recognize that there are many different communities in the region and the dynamics of each single movement have to be taken care of, if any solution is to be achieved. The experience so far with private sector participation in hydro power is also not encouraging in the energy security of Northeastern States. Increasing demand for energy may necessitate a re-look at the present policy regime regarding investment hydro project. Transforming Northeastern States is still as distant dream of Northeast. In this context it is imperative to examine whether the existing development strategy is suitable for NER or is there any new strategy for development. The paper also tries to highlight the issues and challenges confronting Northeastern Region development strategy.
\end{abstract}

Keywords: Energy Security, Dependency syndrome, Dimension of Disparity

\section{INTRODUCTION}

There is often an illusive generalization and tendency about the whole northeastern region as a homogeneous entity by scholars and policymakers to club the whole northeastern states together as "Northeast" and use the term as an analytical category for the whole region.

However, the practical relevance of clubbing all the eight states together and calling it the "Northeast" is always questioned. The use of the term "Northeast" is itself problematic as the region represents a varied cultural mosaic and has never considered itself to be one compact unit. One has to recognize that there are many different communities in the region and the dynamics of each single movement have to be taken care of, if any solution is to be achieved. The fact that each state has a different set of location-specific concerns and grievances often gets blurred in 


\section{International Journal of Social Science and Economic Research}

ISSN: $2455-8834$

Volume: 05, Issue: 06 "June 2020"

the scheme of things of policy framers and government leaders who are supposed to address these issues". It is true that the northeastern region shares certain common problems like ethnic unrests, insurgency, immigration, drug trafficking, communication gap, etc. However, there are severe intra-regional differences in social issues and ethno-political aspirations. The region is, in fact, one of the most ethnically and linguistically diverse region in Asia and each state has its distinct cultures and traditions. The bulk of the literature on NER has emphasized the deficits in institutional capacity of the government, poor infrastructure, poor quality and reach of public service delivery.

The trends in infrastructure deficit and poor quality of public service delivery cannot be reversed unless the deficit in the institutional capacity of the government is addressed as the primary need of the State. Given these attenuating circumstances, the NER's capacity to build infrastructure and ensure public service delivery comparable to the national average remained severely constrained.

\section{DIMENSION OF DISPARITY NORTHEASTERN STATES}

After the inception of Indian planning, the regional disparity of northeast with the rest of the India is widening. The Vision NER 2020 statement argues that, "At Independence, the Northeast region was among the most prosperous regions of India. Sixty years on, the region as a whole and the states that comprise it, are lagging behind the rest of the country in the most important parameters of growth" the basic reason to be sought in India's planning development strategy itself. This strategy centered on rapid industrial development through investment in heavy industries, which would uplift the living conditions of the entire Indian population. But, the strategy failed as it was wrought with mismatch of approaches. The development policies of the successive governments were more in tune with the socio-political consideration rather than socio-economic distributive justice and economic efficiency criteria. As Myrdal points out, on a low level of economic development with relatively low spread effects, the competitive forces in the markets will tend to increase regional inequalities which in turn will hamper economic development and at the same time weaken the egalitarian polices of the governments. But a higher level of development will bring about higher spread effects and this will bring about a reduction in regional inequalities and herein lies the possibilities of convergence in inter regional growth. Unfortunately, in the Indian case, there has been no realization of such convergence. This could be permanently attributed to continuous low national economic growth performance. The key for realizing such convergence is the degree of infrastructure and human capital development, which must come on a priority basis from the state government, with reasonable support from the Central Government. If convergence does not take place, regional disparity 
International Journal of Social Science and Economic Research

ISSN: $2455-8834$

Volume: 05, Issue: 06 "June 2020"

would tend to widen. Here it will be quite relevant to study the dimension of disparity of Northeast. Northeast India still remains at the periphery of Indian growth scenario.

Table 1: Ranking of Northeastern NSDP at Constant Prices Net State Domestic Product at constant prices (2004-05) (Rs. In Crores)

\begin{tabular}{|l|l|l|l|}
\hline States & $2004-05$ & $2010-11$ & $\begin{array}{l}\text { 2004-05 to 2010-11 } \\
\text { (Annual } \\
\text { Growth } \\
(\%\end{array}$ \\
\hline Arunachal Pradesh & 3188 & & 10.09 \\
\hline Assam & 47181 & 5119 & 6.33 \\
\hline Manipur & 4603 & 65102 & 6.71 \\
\hline Meghalaya & 5846 & 6458 & 10.06 \\
\hline Mizoram & 2400 & 9375 & 12.22 \\
\hline Nagaland & 5421 & 4160 & 8.05 \\
\hline Sikkim & 1511 & 8040 & 15.34 \\
\hline Tripura & 8170 & 2902 & 10.65 \\
\hline Total NER & 78320 & 13394 & 7.70 \\
\hline All India & 2651573 & 114550 & 10.49 \\
\hline
\end{tabular}

Source: Central Statistical Organization (MoSPI)

Here, it will be quite relevant to study the dimension of disparity of Northeast. Northeast India still remains at the periphery of Indian growth scenario. Comparing the states within Northeastern states, one finds a huge gap, with Arunachl Pradesh increase NCPSDP from Rs. 3188 in 2004-05 to Rs5119 with annual growth rate of 10.09 percent, whereas Assam the rise is insignificant increase of annual growth of 6.33 percent during the same period. In Manipur the percentage increase of annual growth is 6.71 percent Arunachal Pradesh and Assam are at the top of NCPSDP.

\section{DEGREE OF DEPENDENCY}

To understand the government budget and its functioning in Northeast India, this paper study the degree of dependency of northeastern states. This comparative scenario reflects favorable disbursements. The comparative scenario shows favorable disbursement by the centre to the Northeastern states as compared to the other states India. There is considerable variation in central transfers among the Northeasten states total transfer relative to revenue receipts has been much higher in Nagaland(91.82 percent), and Mizoram (90.91 percent) whearse assam this ratio was as low s 66.15 percent. The share of central taxes in total revenue receipts was the highest in 
Assam (27.42 percent) and the lowest in Sikkim (17.12 percent). Therefore it is evident that amongst the states Sikkim and Assam are least dependent on central assistance. This is because Sikkim has proved to be better managed states with good governance with better economic performance On the one hand Assam has its own resources like oil, tea and others. All the other states have failed to generate resources that could sustain them and are heavily dependent on central funding. Public investment has been going up significantly in the Region.

Table 2: Central transfers as a Ratio of revenue Receipts (1991-2010)

\begin{tabular}{|l|l|l|l|}
\hline States & $\begin{array}{l}\text { Total transfers } \\
\text { relative to Total } \\
\text { Revenue Receipts }\end{array}$ & $\begin{array}{l}\text { Share of central } \\
\text { taxes in total } \\
\text { revenue Receipts }\end{array}$ & $\begin{array}{l}\text { Grants in aid to } \\
\text { Revenue Receipts }\end{array}$ \\
\hline Assam & 66.15 & 27.42 & 38.73 \\
\hline Nagaland & 91.82 & 27.42 & 69.83 \\
\hline Meghalaya & 81.61 & 23.63 & 57.98 \\
\hline Sikkim & 79.02 & 17.12 & 61.90 \\
\hline Manipur & 91.18 & 23.17 & 68.00 \\
\hline Tripura & 87.98 & 21.99 & 63.71 \\
\hline Arunachal Pradesh & 87.88 & 18.29 & 69.58 \\
\hline Mizoram & 90.91 & 20.80 & 70.11 \\
\hline
\end{tabular}

Source: Compiled from handbook of Statistics on Sate Government Finances

\section{ENERGY SECURITY}

There is a significant development for Northeast which has enormous hydro potential far exceeding the region's internal requirement of the power. At all India level, only 17 percent of the available hydro potential has been harnessed so far. The total unexploited hydro-power potential in the country is $65599 \mathrm{M}$, of this $32,367 \mathrm{MW}$ around 50 percent is in the NER. The issues relating to forest and environmental clearance rehabilitation of projects affected people, law and order problems would also pose a serious problem and delay in project implementation there are also demand for enhancement of poor share from various quarter to the host country from the present label of 12 percent and for further additional benefit. Such demand may 
International Journal of Social Science and Economic Research

ISSN: $2455-8834$

Volume: 05, Issue: 06 "June 2020"

necessitate a re-look at the present policy regime regarding investment hydro project. The experience so far with private sector participation in hydro power is also not encouraging.

It would also be good idea for northeastern government to take equity participation the public sector company in lieu of their share of free power. The public also should be given a chance to contribute to the share capital of the public share when they are ripe for public issue.

Another model for hydro power development that can be attempted in northeastern is investment by other power deficit states or consortia of states as joint venture with northeastern states especially Arunachal Pradesh which has sizable hydropower potential. This would be a feasible option as trading in power is permitted.

\section{CONCLUSION AND OBSERVATION}

It is evident from that, Northeast India still remains at the periphery of Indian growth scenario and a higher level of development will bring about higher spread effects and this will bring about a reduction in regional inequalities and herein lies the possibilities of convergence in inter regional growth. Unfortunately, in the Indian case, there has been no realization of such convergence. This could be permanently attributed to continuous low national economic growth performance. The key for realizing such convergence is the degree of infrastructure and human capital development, which must come on a priority basis from the state government, with reasonable support from the Central Government. If convergence does not take place, regional disparity would tend to widen.

It is evident that amongst the states Sikkim and Assam are least dependent on central assistance. This is because Sikkim has proved to be better managed states with good governance with better economic performance On the one hand Assam has its own resources like oil, tea and others. All the other states have failed to generate resources that could sustain them and are heavily dependent on central funding.

The experience so far with private sector participation in hydro power is also not encouraging. Regarding energy security in Northeastern states, It would also be good idea for northeastern government to take equity participation the public sector company in lieu of their share of free power.

\section{REFERENCES}

Ahluwalia, M.S. 2000, "Economic Performance of States in Post-Reforms Period", Economic and Political Weekly, Vol. XXXV, No.19, May 6, pp. 1637-1648. 


\section{International Journal of Social Science and Economic Research}

ISSN: $2455-8834$

Volume: 05, Issue: 06 "June 2020"

Ahmed, Rafiul and Biswas, Prasenajit 2004. Political Economy of Underdevelopment of NorthEast India. New Delhi: Akansha.

Avijit Debnath and others (2013). Transfer Dependence of Northeastern States: Are the Growth Effects of Grants Uniform Across States? Margin-The journal of Applied Economic Research 7:1

Debasis Neogi (2010). "Disparity in Socio-Economic Development and Its Implications on Communal Conflicts": A Study on India's North-Eastern Region International Journal of Human and Social Sciences 5:5

Chattopadhyay, M., Mukherjee, R. and Ashok Rudra 1990. "Disparities in Income and Level of Living", Economic and Political Weekly, Vol. XXXV, No. 15, April 14, pp. 789-790

Goswami, A. (eds.) 2001. Regional Disparities in India, Akansha Publishing House, New Delhi

J. Dreze and A. Sen, 1995. India: Economic Development and Social Opportunity', Oxford University Press.

J. Dreze and A. Sen, 2010 . India Development and Participation Oxford University Press

Montek S.Ahluwalia 2002,Economic Performance of states in Post Reform Peroid", Economic political Weekly May 6 p137-1648

N.J. Kurian (2003). “Widening Regional Inequalities in India: Some Indicators”, Economic and Political Weekly 35(7) pp.538-550

Pallabi Borah(2009). NEC and the Development Initiatives in the Northeast Dialogue January March, Volume 10 No. 3

Sarkar, P. C. (1994), "Regional Imbalances in Indian Economy over Plan Periods", Economic and Political Weekly, Vol. XXIX, No.11, March 12, pp. 621- 623

Thongkholal Haokip 2011. "Conceptualizing Northeast India: A Discursive Analysis on Diversity “, Bangladesh e-Journal of Sociology. Volume 8, Number 2. July 109

Report (2001) of the Working Group on Agricultural Development in Eastern \& Northeasterb India for the Formulation of the Tenth Five Year Plan, Government of India, Planninng Commission August.

Report (1981) on General Issues Relating to Backward Areas Development 
International Journal of Social Science and Economic Research

ISSN: 2455-8834

Volume: 05, Issue: 06 "June 2020"

November, Planning Commission Government of India, New Delhi

Planning Commission August 2011. Approach to 12 the five year plan period

Ministry of DoNeER Annual Report 2012-13

Ministry of DoNeER \& NEC VISION 2020 Vol.1

Yojana, Dec. (2008). December Special Northeast issue 